\title{
Impacts of Oil Exploration on the Livelihoods of agro-pastoralists in Western Kordofan State-Sudan
}

\author{
Mahir Salih Suleiman Khaleel, Elmalieh Mohammed Ahmed \\ College of Forestry and Range Sciences, Sudan University of Science and Technology. P.O. Box 6146 \\ Khartoum, Sudan. \\ PhD candidate, College of graduate studies, Sudan University of Science and Technology.
}

\begin{abstract}
Mostly local communities perceive oil discovery in their areas as an opportunity to improve their livelihoods. They expect better access to the resources needed for a decent standard of living, though that might not always be the case. Pastoralist and subsistence farming have traditionally been the two main livelihood systems in the study area, however their life began to change recently as a result of oil exploration. In spite of the huge resources generated from the area still communities are lagging behind and suffering from the lack of basic social services. The study intended to answer the following question: What is the impact of oil exploration on the livelihoods of agro-pastoralists in West Kordofan State-Sudan? The overall objective of the study is to investigate the oil exploration and its impact on Agro-pastoralists in West Kordofan State and scrutinize the character of the changes occurred in various aspects of their livelihood.

The study opted for qualitative descriptive survey approach, deploying primary and secondary data. Using the structured interviewing technique 200 households and 30 key informants were interviewed at Kailak and Elsalam localities. In addition focus groups discussions were carried out with stakeholders in the selected villages. The study disclosed that three out of the five livelihood asset types need to be strengthened in order to come up with the desirable development. Livelihood outcome within communities were very weak as there was no major positive change in economic and livelihood situation. It seems that intervention towards improvement of traditional production system and technology used in agriculture was insufficient. It is evident that lack of coordination with the localities' authorities in the infrastructure and social services provision has resulted in unsustainable deliverance. However, both official and traditional local institutions are too weak and of very limited capacity to be effectively engaged in the development process. Improving livelihoods outcome will require a multi-stakeholder approach to oil exploration involving the local government, oil companies and host communities. Inevitability this will entail capacity building and training of local communities to enable them to actively participate in the sustainable development of their areas.
\end{abstract}

Keywords: Oil production, Sustainable Livelihood, Community Development

\section{Introduction}

Many studies revealed that oil exploration have negative impacts not only by threatening the health of local communities, but also their livelihoods. In Nigeria, poverty increase was attributed to oil pollution in the host communities that deprived the communities' profitable livelihood activities, particularly farming and local enterprises (Ojo, 2002 and Chikanda, 2009). According to the World Bank (1993) the consequence of oil exploration in the local economy had resulted in decreasing economic activities (particularly agricultural) leading to decreasing outputs of crops and declining rural economy. Meanwhile, local communities look forward to development and services as dividend of oil production in their areas. They expect better access to the resources needed for a decent standard of living (UNDP, 2012).

According to Christenson and Robinson, (1989) community development is a process that increases choices. It means new options, diversification, thinking about apparent issues differently and anticipating change. It is the creation of wealth, wealth meaning the things people value, not just dollars (Shaffer, 1989). It leads to a net addition to community assets, avoiding the "zero sums" situation where a job created "here", is a job lost "there". Community development improves the ability of communities to collectively make better decisions about the use of resources such as infrastructure, labor and knowledge aiming at improving the social, economic and environmental situation. Development therefore is related to empowerment: it is about local people taking control of their own lives, expressing their own demands and finding their own solutions to their problems (Alkire, 2010).

The livelihoods' approach has evolved principally as an analytical tool that seeks to provide a logically consistent means for thinking through the complex issues and factors that influence the lives and wellbeing of the communities (DFID 1999). A livelihood comprises the capabilities, assets including both material and social resources and activities required for a means of living, (Chambers and Conway 1992). Livelihoods can be made 
up of a range of on-farm and off-farm activities, which together provide a variety of procurement strategies for food and cash. Thus, each household can have several possible sources of entitlement which constitute its livelihood. These entitlements are based on the household's endowments and its position in the legal, political and social fabric of society. Household livelihood security is defined as adequate and sustainable access to income and resources to meet basic needs including: adequate access to food, potable water, health facilities, educational opportunities, housing, time for community participation and social integration (Drinkwater and McEwan, 1992).

The prime focus of Sustainable Livelihood (SL) is how people use their assets to enhance their livelihoods. The SL approach groups assets into the following categories:

1. Human capital such as skills, knowledge, the ability to labor and good health that allows livelihood objectives to be achieved.

2. Social capital such as networks and connectedness, membership of formalized groups or relationships of trust, reciprocity and exchanges.

3. Financial capital including available stocks and regular inflows of money.

4. Physical capital including the basic infrastructure and producer goods (or tools and equipment) used to function more effectively; and

5. Natural capital, which is the natural stocks that can be used in developing livelihood strategies, such as land, water, air quality, storm protection.

When investigating livelihood assets it is important to establish the links between assets. Complementarily, nonsubstitutability, access, clustering, sequencing and trends in availability of assets help to determine appropriate strategies in strengthening the livelihood assets (DFID, 1999). The aim of the SL approach is to enhance capability in facing change and unpredictability, improve equity and increase social sustainability by reducing external stress and shocks by providing safety nets (Carney, Diana et al 1999). Livelihood is environmentally sustainable when it maintains or enhances the local and global assets on which livelihoods depend, and has beneficial effects on other livelihoods. A livelihood is socially sustainable when it can cope with and recover from stress and shocks, and provide for future generations (Chambers and Conway, 1992). Strengthening livelihood assets may be carried out through such strategies as reconstructing grassroots organizations, transforming between the community and local government, developing collective knowledge and skills or redeveloping urban infrastructure (DFID, 1999). In rural communities, livelihood strategies may include diversification, migration and agricultural intensification. The use of the SL approach aims to enhance livelihood strategies, rather than change them. By understanding the factors that direct people's choices towards particular strategies it is possible to then reinforce the factors that promote flexibility within these strategies. Negative influences or constraints, such as inadequate market access, degraded natural resources or climatic risk or uncertainty can be militated against (DFID, 1999).

The economy of West Kordofan State is predominantly dependent on agricultural production consisting of rain fed cultivation and traditional livestock raising practiced by nomadic and semi-nomadic agro pastoral and sedentary groups (IFAD, 2012). The main types of livelihood systems are nomadic and semi-nomadic pastoralist, sedentary agro-pastoralist, agriculture and forests based activities. The traditional land use pattern of Meserya tribes (the inhabitants of the area) was practicing open grazing. They are cattle breeders and few of them are farmers who cultivate some crops to be used for their daily uses. Recently their life began to change as a result of oil exploration which affected their livelihoods pattern economically, socially, and environmentally. In spite of the huge resources generated from the area still communities are lagging behind and suffering from the lack of basic social services such as health, education and clean water. It seems that oil companies and the concerned ministry did not take enough measures to upgrade the local communities' capacity and integrating them to grantee smooth and sustainable development.

The study is aiming to answer the following main question:

\section{What is the impact of oil exploration on the livelihoods of the local communities in West Kordofan State- Sudan?}

The overall objective of the study is to investigate the oil exploration and its impact on Agropastoralists in West Kordofan State and scrutinize the character of the changes occurred in various aspects of their livelihood. The study will be focusing on the change in rural livelihood as main measure to assess progress of communities' well-being and changes occurred in the traditional socio-economic patterns of pastoralist settlers around the oil fields.

\section{Research Focus And Methodology}

The study opted for qualitative descriptive survey approach, deploying primary and secondary data. Considering the household as a unit of analysis 200 households were selected randomly. The survey was conducted in two localities in West Kordofan state namely: the Kailak and Elsalam. 
Two sets of questionnaires were used for interviewing the respondents. The first set was used to collect data from the 200 household heads, whereas the second was administered to interview 30 key informants. The key informants included officials (teachers and health cadres), leaders of local administrations, and local community leaders including old and well oriented community members. In addition Focus Groups Discussions were carried out with stakeholders in the selected villages. The secondary data was obtained from; Government administrations reports and NGOs records.

The study area lies between longitudes $270 \quad 10^{\prime}-290 \quad 58^{\prime} \mathrm{E}$ and latitudes 090 00'-120 00' $\mathrm{N}$. Temperatures range from $24^{\circ} \mathrm{C}$ in May to $13^{\circ} \mathrm{C}$ in January. Rainfall is highly seasonal and erratic, going from more than $750 \mathrm{~mm}$ in the south to less than $200 \mathrm{~mm}$ in the north. Drought is frequent, occurring one year in ten on average in the higher rainfall areas of the south, and in recent times three years out of ten in the north (IFAD, 2012). Pastoralist and subsistence farming have traditionally been the two main livelihood systems in the area. However, worth noting is the fact that there had never been a clear division between the two livelihoods systems as many households are engaged in both, combining pastoralist and farming (El Sammani and Salih, 2006).

\section{Results And Discussion}

\section{Introduction}

The livelihoods approach is deployed for the analysis of the research data. In fact the research area is very rich with natural resources. Traditionally, households have been using diverse strategies to access these resources involving both tangible and intangible assets that allow them to meet their basic needs. We would go through the Household Livelihood Framework which consists of five assets.

\section{Natural Capital}

It consists of natural resource stocks from which useful resource flows or derived for livelihoods maintenance. In this respect, land is available but conflict started after oil exploration even among the one family member due to the benefit of land compensation processes.

The concept of compensation is a key element of Meserya local culture. It enters into all relations, starting with marriage, and is involved in addressing grievances or crimes. Local communities whose rights have been violated by oil exploration are entitled for compensation to land used in oil production. On the one hand, this has prompted land disputes, as individuals scramble to get hold of land rights with the expectation of reaping from the boom in land market due to oil discovery. On the other hand, efforts to appropriate land from groups without giving them a voice in the decision-making process and without what they perceive to be equitable compensation might lead to rising social tensions and outbreaks of rebellion. Unfortunately, compensation has increased the tribal conflicts over the land. In November 2011 a conflict between two tribes resulted in the loss of 200 persons. Another conflict happened during January 2013 where more than 200 other people were killed, and still the problem was not solved and the conflict over land exists.

Historically, this area was the natural pasture of Meserya tribes during dry season. Usually, they used to spend more than five months with their cattle and sheep in this area. However, due to oil exploration, the majority of them were leaving to other areas. Meanwhile other people are coming seeking for jobs and services, especially the services of water provided by companies in dry season.

Damage resulting from petroleum exploration activities in pastoral areas includes interruption of stock routes and changing the course of direction of water runoff. The natural drainage system (inflows and outflows of rain water) have totally been changed due to construction of roads, embankments and bridges against the normal cantor lines. This on the one hand adversely affected normal replenishment of natural ponds and water bodies such as Lake Kailak. On the other hand, accumulation of water and flooding in some areas caused death of trees and diminished cultivable land. Additionally, it was observed that sometime companies use seasonal natural drainage system for disposal of waste water without considering the negative impact to human and animals' health. Hence, most of the respondents (90.5\%) declared that their agricultural land, forests, ranges and wildlife habitat were miserably affected (table 1).

Table No. 1: Oil exploration destructively impacted agricultural, forests and ranges land

\begin{tabular}{|l|l|l|l|}
\hline Responses & Frequency & Percent & Cumulative \\
\hline Yes & 181 & 90.5 & 90.5 \\
\hline No & 19 & 9.5 & 100.0 \\
\hline Total & 200 & 100.0 & \\
\hline
\end{tabular}

Source: (Field survey, 2011).

\section{Financial Capital}

It includes cash and other liquid resources. In this respect, the communities are facing problems to deal with banks. In fact there were no institutional finance and credit system to serve local communities. There was no single bank in all the surveyed area, and only very few households (less than one percent) are dealing with 
the banking system while the majority of respondents $(99.5 \%)$ are not familiar with it and they have no accounts at all (table 2). It is evident that they did not encounter with any type of financial institution that help the communities in credit and finance. Hence, communities have established their businesses largely through informal credit and personal funds. Some of the households depend on remittances of their relatives either inside or outside Sudan.

Table No. 2: Households' familiarity with banking system

\begin{tabular}{|l|l|l|l|}
\hline Responses & Frequency & Percent & Cumulative \\
\hline familiar & 1 & $0.5 \%$ & 0.5 \\
\hline not familiar & 199 & $99.5 \%$ & 100.0 \\
\hline Total & 200 & 100.0 & \\
\hline
\end{tabular}

Source: (Field survey, 2011).

\section{Physical Capital}

It includes basic infrastructure and assets which are considered as one of the major indicators for household livelihood security. According to the study, the most common assets owned are the radios, while television and refrigerators are only used where electricity supply is available.

As displayed in table 3, traditional wells and boreholes are the major sources of drinking water as stated by $61.5 \%$ of the respondents. Worth mentioning is the fact that presently $34.5 \%$ depend on mobile trucks from oil companies that provide water to communities crossing long distance as direct delivery of services.

Table No. 3: Sources of water for household consumption

\begin{tabular}{|l|c|c|c|}
\hline Responses & Frequency & Percent & Cumulative \\
\hline Boreholes & 123 & 61.5 & 61.5 \\
\hline surface & 7 & 3.5 & 65.0 \\
\hline Small damps & 1 & 0.5 & 65.5 \\
\hline Companies' tankers & 69 & 34.5 & 100.0 \\
\hline Total & 200 & 100.0 & \\
\hline
\end{tabular}

Source: (Field survey, 2011)

As concern energy sources, the study pointed up that most of the villagers are depending on kerosene for lighting purpose. Other sources include: private local generators, whereas solar and gas energy was mentioned with negligible proportions in all communities.

Regarding cooking energy source, table 4 showed that $99 \%$ of respondents were using wood while only $1 \%$ was using charcoal. Noteworthy is that no household was reported to be using gas.

Table No. 4: Type of energy source used for cooking

\begin{tabular}{|l|c|c|c|}
\hline Responses & Frequency & Percent & Cumulative \\
\hline firewood & 198 & 99.0 & 99.0 \\
\hline charcoal & 2 & 1.0 & 100.0 \\
\hline gas & 0.0 & 0.0 & 100.0 \\
\hline Total & 200 & 100.0 & \\
\hline
\end{tabular}

Source: (Field survey, 2011).

Table 5 pointed out that $96.5 \%$ of the respondents dwell in temporary houses built of local materials such as wood and grass while only $3.5 \%$ reported that their houses are permanent (built from mud). In fact, there are three types of tents, each built for a different purpose. However, locally gathered fibrous construction materials are essentially the same. The three tent types are: (1) the portable trek tents (2) the jahoba; and (3) the humar or dahur al-Tour. The first type is used during transhumance and the beginning of the dry season, while the latter two types are dry season structures. During the field work no household reported as using bricks. Moreover, the great majority of the houses were not fenced. These types of houses are not changed even after the discovery of oil.

Table No. 5: Nature of Family Housing

\begin{tabular}{|l|c|c|c|}
\hline Responses & Frequency & Percent & Cumulative \\
\hline Permanent & 7 & 3.5 & 3.5 \\
\hline Temporary & 193 & 96.5 & 100.0 \\
\hline Total & 200 & 100 & \\
\hline
\end{tabular}

Source: (Field survey, 2011). 
Almost all households that have latrines are of the traditional type and these constitute $34.5 \%$. According to table 6 , households without latrine at all amount to $65.5 \%$ of respondents.

Table No. 6: The nature of household latrines

\begin{tabular}{|l|c|c|c|}
\hline Responses & Frequency & Percent & Cumulative \\
\hline Yes & 69 & 34.5 & 34.5 \\
\hline No & 131 & 65.5 & 100.0 \\
\hline Total & 200 & 100.0 & \\
\hline
\end{tabular}

Source: (Field survey, 2011).

The issue of reproductive health in the area is very poor. The lack of nearby health facilities for the presentation of primary health care services and health extension to the families is resulting in increased mortality rate among pregnant women and children during delivery.

Table No. 7: Character of Midwives in the study area

\begin{tabular}{|l|c|c|c|}
\hline Responses & Frequency & Percent & Cumulative \\
\hline Traditional (Habel) & 94 & 47.0 & 47.0 \\
\hline TBA & 23 & 11.5 & 58.5 \\
\hline Trained Midwives & 83 & 41.5 & 100.0 \\
\hline Total & 200 & 100 & \\
\hline
\end{tabular}

Source: (Field survey, 2011).

In this connection, table 7 illustrated that still the communities are largely (47\%) relying on traditional midwives (Dayet Habel).

As for communication facilities, the telecommunication networks are available and most of the people are using mobile phones. In general, the situation now is better than before, however, the area is facing serious problem of infrastructure provision. Still communities are using local means of transport such as donkeys and camels. However, sometime local people use oil companies' trucks to travel. Furthermore many villages are inaccessible during the rainy season due to lack of asphalt roads.

According to table 8 farming constitutes the main occupation for almost $35 \%$ of the respondents, when adding herding and agro-pastoralist the percentage mounts to $68 \%$. Though main occupations remained as before oil exploration, but other jobs have appeared, including; working in oil companies, casual labors and retail trading. Obviously, on the one hand these emerging new sources of livelihood are adding value to the rural economy of the area. On the other hand, some of those activities are putting more burdens on natural resources, especially those related to cutting of wood and making charcoal.

Table No. 8: Occupation of the household's head

\begin{tabular}{|l|c|c|c|}
\hline Responses & Frequency & Percent & Cumulative \\
\hline Farming & 70 & $35.0 \%$ & $35.0 \%$ \\
\hline Herding & 17 & $8.5 \%$ & $43.5 \%$ \\
\hline Argo-Pastoralist & 49 & $24.5 \%$ & $68.0 \%$ \\
\hline Trade & 15 & $7.5 \%$ & $75.5 \%$ \\
\hline Unemployed & 5 & $2.5 \%$ & $78.0 \%$ \\
\hline Casual Worker & 23 & $11.5 \%$ & $89.5 \%$ \\
\hline Other & 21 & $10.5 \%$ & $100 \%$ \\
\hline Total & 200 & $100.0 \%$ & \\
\hline
\end{tabular}

Source: (Field survey, 2011).

Agricultural activities represent the common indicator to measure the household livelihood situation. When addressing the issues of supporting the agricultural activities in the area, the study revealed that provision of agricultural inputs to enhance the production system of local people was very limited as $94.5 \%$ of the respondents indicated that they did not receive any type of assistance or technical support (table 9). The remaining 5.5\% who admitted getting inputs indicated that was eight years ago in Kailak locality from the Tales Man Company.

Table No. 9: Provision of Agricultural Inputs

\begin{tabular}{|l|c|c|c|}
\hline Responses & Frequency & Percent & Cumulative \\
\hline Yes Provided & 11 & 5.5 & 5.5 \\
\hline Not provided & 189 & 94.5 & 100.0 \\
\hline Total & 200 & 100.0 & \\
\hline
\end{tabular}

Source: (Field survey, 2011). 
One of major problems regarding the services delivered by oil companies was that they did not adopt any development approach that allows communities participation to identify their needs. It is logical that the delivery of services without upgrading local communities' skills and knowledge will not sustain.

Group discussions spelled out the extent of dissatisfaction among local people as concerns the status of the social services availed in the study area.

\section{Human Capital}

It represents the skills and knowledge. The quality of the human resources base has been seen as most significant structural weakness in study area. Educational level of communities' members is low compared with other areas of the Sudan due to the nature of agro-pastoralists and nomadic communities. This is not surprising, in light of the comparatively short history of education. Table 10 illustrated that $47 \%$ of the households' heads are illiterate, while $28 \%$ completed only primary education.

Table No. 10: Educational Level of the Households' Heads

\begin{tabular}{|l|c|c|c|}
\hline Responses & Frequency & Percent & Cumulative \\
\hline Illiterate & 94 & $47.0 \%$ & 47.0 \\
\hline Khalwa & 19 & $9.5 \%$ & 56.5 \\
\hline Primary /Basic & 56 & $28.0 \%$ & 84.5 \\
\hline Intermediate & 13 & $6.5 \%$ & 91.0 \\
\hline Above Secondary & 18 & $9.0 \%$ & 100.0 \\
\hline Total & 200 & 100.0 & \\
\hline
\end{tabular}

Source: (Field survey, 2011).

The impact of education in terms of availability and accessibility of services was discussed within focus groups. Those discussions indicated that access to basic education service has improved, however the overall environment of basic education needs a lot to be described as suitable. Most of the schools were built with local materials and were not completed. More often than not, those schools were facing problems such as: shortage of teachers, accommodation or seating. Furthermore, discussions revealed still the existence of the phenomenon of children not going to schools. According to local people this phenomenon is mainly attributed to involvement of children in performing other tasks like agriculture and herding. In reality, many parents need their children to work to assist them in maintaining their livelihood. Nonetheless, still some children do not go to school due to remoteness of the schools.

Focus group discussions revealed that, despite the numerous employment opportunities coming with the prospecting for oil, in nearly all localities, communities felt that they were not being given fair consideration in the recruitment process by oil companies. Companies did not give any priority to local people even for unskilled work. Hence, local people reluctantly looked at the aspect of employing persons who are not indigenous to the area as unjustified. Moreover, the income generated from working in Oil companies is contributing very little to livelihood situation and well-being of households. That might be because most of them are working as casual labors with low wages compared to technical jobs and skilled labors. Furthermore, there is no long-term strategy to train and build the capacity of local people. Hence, voices are coming up to absorb the youth in vocational training and technical institutes to supply locally the required skills labors.

\section{Social Capital}

Communities depend on tribal ties and traditional family network system rather than the formal and organized institutions of civil society. They use these networks to reduce risks, access services, protect themselves from deprivation. In fact the concept of civil society needs to be considered by oil companies to substitute the inherited tribal system.

Oil exploration is expected to provoke economic, social, and cultural changes. The extent of these changes is especially important to local people particularly indigenous people who have traditional lifestyle. One profound social effect of oil prospecting has been the opening up of communities that were generally closed to external influences. Socio-cultural system changed such as social structure, organization, cultural heritage, practices, believes and surfacing of new habits and behaviors.

Table No. 11: Character of behavioral changes among local people

\begin{tabular}{|l|c|c|c|}
\hline Responses & Frequency & Percent & Cumulative \\
\hline Using drugs & 15 & 7.5 & 7.5 \\
\hline General behavioral change & 143 & 71.5 & 79.0 \\
\hline Smoking & 18 & 9.0 & 88.0 \\
\hline Others & 24 & 12.0 & 100 \\
\hline Total & 200 & 100.0 & \\
\hline
\end{tabular}

Source: (Field survey, 2011). 
Among the most affected categories were the: youth, women and laborers working in oil companies. These groups have been undergoing changes in various ways such as types of clothes, smoking, and drugs and committing crimes that were never reported before (table 11).

\section{Conclusions: revisiting the livelihoods' framework}

The study disclosed that three out of the five livelihood asset types need to be strengthened in order to come up with the desirable development.

Livelihood outcome within communities as depicted through looking into various indicators were very weak especially as concern health outcome, saving, consumption, income, food security and sustainable use of natural resources. This indicated that there was no major change in economic and livelihood situation. It seems that intervention towards improvement of traditional production system and technology used in agriculture was insufficient. In fact there was no significant change in local agriculture production system including patterns of animal production and breeding already practiced in the area. In addition, there was no noteworthy impact on families' livelihood pattern e.g. owning luxuriousness goods as local people are still using traditional and poor household assets. Further, there was no change in the form of houses as still houses are constructed with local material with no fence and latrines.

The positive economic impact among the local people are the employment opportunities, however many of them are working as casual laborers with no transparent recruitment process. It seems that oil companies are in favor of employing of immigrant workers, while local people are still jobless.

Lack of coordination with the localities' authorities in the infrastructure and social services provision has resulted in unsustainable deliverance. Both official and traditional local institutions are weak and of very limited capacity. Hence, they are not effectively engaged in development processes.

Improving livelihoods outcome will require a multi-stakeholder approach to oil exploration involving the local government, oil companies and host communities. The multi-stakeholder mechanism should address issues of livelihood strategies such as: development projects, employment opportunities and capacity building and training of local communities to enable them build on or transfer their assets base.

\section{References}

[1]. Alkire, S. (2010). Development: A Misconceived Theory Can Kill. In: Christopher W. Morris (ed.), Amartya Sen. Cambridge University Press.

[2]. Carney, D., Drinkwater, M., Rusinow, T., Neefjes, K., Wanmali, S. and Singh, N. (1999). Livelihoods Approaches Compared. Department for International Development. London.

[3]. Chambers, R. and G. Conway (1992). Sustainable Rural Livelihoods: Practical Concepts for the 21st Century. Institute of Development Studies. Discussion Papers, 296. Cambridge.

[4]. Chikanda, A. (2009). Environmental Degradation in Sub-Saharan Africa. In: Environment and health in Sub-Saharan Africa eds Springer Netherlands.

[5]. Christenson, J.A. and J.W. Robinson (1989). Community Development in Perspective. Iowa State University Press .

[6]. Drinkwater, M. and M. McEwan (1992). Household food security and environmental sustainability in farming systems research: developing sustainable livelihoods. Paper presented to the Adaptive Planning Research Team Bi-annual Review Meeting, Mangu, Zambia, 13-16 April.

[7]. El Sammani, M. O. and A. A. Salih (2006). Nomads' Settlement in Sudan: Experiences, Lessons and Future Action. Khartoum: UNDP.

[8]. IFAD (2012). Western Sudan Resources Management Programme (WSRMP) Report. Ministry of Agriculture and Animal Wealth.

[9]. Ojo, J.B. (2002). The Niger Delta: Managing Resources and Conflicts. Research Report, Development Policy Centre, Ibadan, 49: 157.

[10]. Shaffer, R. (1990). Building economically viable communities: a role for community developers. Journal of the Community Development Society. Volume 21, Issue 2.

[11]. The Department for International Development (DFID), (1999). Sustainable Livelihood Guidance Sheet Section 2. London.

[12]. World Bank (1993). Irrigation Programme Coordination Unit (PCU), South Kordofan State: Poverty reduction Handbook. 